\title{
The Polish Theatre of Death
}

\section{Abstract}

There is probably no doubt, that black thread of mourning deeply penetrates the tissue of Polish life. And this is true for many areas of life. From a specific model of Polish Catholicism (with the strongly expressed theme of a crucified Christ), through behaviour in the public space (funerals of great artists and politicians, which become spectacles of patriotism), through to works of art (theatres filled with spirits of the dead and great movie achievements). For the past two centuries death has been a non-negotiable element of our symbolic equipment, an ideological foundation of the Polish collective imagination. Death in its essence - experienced, shown, played - has occupied a prime position in Polish mythology over the last two centuries. And such mythology, as I understand it here, is not just fiction, falsehood or fabrication. Although it has been woven with beliefs and ideas, it leads a real life of its own and has real power over the thinking and behaviour of those who believe in it.

Keywords: death, mourning, ritual, myth, mentality, ideology.

1.

History is not only a matter of politics. It is impossible to reduce history to individual events strung along a causal link. The past consists not only of the most visible and frequently described "foam of events", but also the whole sphere of semipalpable anticipations, beliefs, images and phantasms, what anthropology refers to as collective mythology, that which creates spaces of "long duration", a substrata upon which the political element is built.

If one looks upon the last two hundred years of Polish history (the third partition of Poland in 1795 may serve as a turning point) from the point of view of a history of mentality (thought/ideas?), if the history of Poles is consider from the collective psychological point of view, then, in this panoramic image, it would be easy to find a solid component: the figure of death, the topos of death. In the 
first instance, the real death of real people filling real cemeteries. But over these corpses and over all these years a thick symbolic shroud has been woven.

There is probably no doubt that this black thread of mourning deeply penetrates the tissue of Polish life. And this is true for many areas of life. From a specific model of Polish Catholicism (with the strongly expressed theme of a crucified Christ), through behaviour in the public space (funerals of great artists and politicians, which become spectacles of patriotism), through to works of art (theatres filled with spirits of the dead and great movie achievements). Death may be a master in Germany, but apparently doesn't do too badly for itself in Poland either. For the past two centuries it has been a non-negotiable element of our symbolic equipment, an ideological foundation of the Polish collective imagination. Death, or a black banner, under which - as under a large umbrella - we can all find shelter.

Death in its essence - experienced, shown, played - has occupied a prime position in Polish mythology over the last two centuries. And such mythology, as I understand it here, is not just fiction, falsehood or fabrication. Although it has been woven with beliefs and ideas, it leads a real life of its own and has real power over the thinking and behaviour of those who believe in it.

\section{2.}

In the author's note to the second part of the drama Forefather's Eve, Mickiewicz feels compelled to explain why he had given his drama such a quaint title: "FOREFATHER'S EVE". This is the name of the ceremonies celebrated among common folk in many districts of Lithuania, Prussia and Courland, in remembrance of their forefathers, that is collective deceased ancestors. He also added that since the clergy had sought to eradicate this custom, "the populace celebrates its Forefathers secretly nearby to the cemetery, in chapels or empty houses". Mickiewicz sensed it well: "the spirit of Polishness" lives in a cemetery, or in its vicinity. He recognised in his masterly drama the needs of the national community and gave to it a theatrical dimension, furnishing - and for a long time - Polish consciousness (and sub-consciousness), codifying the rules of the national and patriotic game.

Whether we know it or not, whether we want it or not, whether we like it or not - we are all the product of our forefathers. From the theatre and from rites hence comes our modern founding myth. At the same time it is not surprising, perhaps, then that deprived of its statehood, nineteenth century Poland (with an extension to 1918) was so strongly rooted in the romantic drama and in the November festival of the dead - the Forefather's eve. The communion of the living and the dead became a national ritual and that parlance of corpses appealed to Poles in a special way. The surprising thing is that the restoration of independence, two world wars, 
communist ideology and - as we shall see - dogmatic capitalism undermined the myth very little. We still find ourselves in a theatrical gesture of communing with the dead and in the All Soul's day rite. A past strewn with corpses and ghosts it is not for us an alien world. On the contrary, this is where we feel most at home.

A significant fact is that when staged after World War II, Forefather's Eve was for Polish consciousness more than just a routine item in the theatrical repertoire. It became a national cause. It was not only theatre, it was - or so the audience perceived it to be - presented as a dramatic form of life, our life. The forefathers of Swinarski, Dejmek, Grzegorzewski became a remarkably sensitive seismograph of Polish mentality; we have viewed and interpreted them, but they have also watched and interpreted us. And the Gardzienice Sorcery of Staniewski that distils - via Mickiewicz's text - the spiritual essence of Polishness. While The Dead Class, Wielopole, Wielopole, I Shall Never Return by Kantor - what are these it if not a Jewish variation on the summoning of the dead, invoking spirits? Jan Kott wrote about this:

Shortly before the end of the presentation, piled on tables and stools, and school benches in The Dead Class, actors and mannequins sit tight as if glued into each other. The priest in turn calls forth the dead by name and surname. Kantor celebrated his Forefathers' Eve for the last time.

And the November All Saint's Day? We still feel - regardless of our degree of religious commitment - a secret closeness with it, which often becomes a keystone of the family- and national identity. Andrzej Dudziński, the outstanding Polish graphic artist working for many years in New York, when asked at the beginning of the 1990s about his views of our country, replied:

You know, it reminds me of visits to my Grandma. They have always been associated with All Saints Day - I also participated recently in the event and suddenly remembered what it means and how important it is. I remember that we often went to our grandmother's, to Tczew, and there we would visit the graves. (...) And this is what Poland means to me. This is All Saints Day, from which we escaped to those graves.

The collective mind defines the festive hierarchy in its own image and likeness, while often ignoring the official religious dogma. Observing the November mobilisation of Poles, one might think that during these two November days, including All Saints' Day and All Souls' Day, we celebrate our most important Catholic holidays. And like in the forefathers of Adam Mickiewicz, so here through the Christian surface layer, a pagan substrata emerges. Andrzej Stasiuk wrote about this after a visit to the monumental temple in Licheń ("The Eastern Sagrada Familia and the Taj Mahal of my country"). "No, God has ever been needed here, only dozens, hundreds of saints floating in the air like ghosts, plus their goddess. The bones under the earth, the ghosts in the air".

If you look at this Polish relentless experiencing, remembering, re-creating death in life and in art, perhaps instead of the eagle the Polish coat of arms should have a grave or coffin as its emblem. Anyway, in the mythological perspective, 
Poland turns out to be a vast necropolis. Permanent mourning is a way of life and our mental historiography turns thus into necrography.

\section{3.}

In the Polish imagination the paradigm of the romantic experience of death and its placing at the centre of community life still reigns over the souls. We are still suffering from our own native version of Sein zum Tode - implanted to us by the Great Romantics. Death is our national totem. And as in the past, also today, we gather around it during special moments.

The ritual and symbolic space, which opened Mickiewicz's drama and religious festival, is reflected in many events of contemporary public life. The All Saints' Day theatre has occupied a privileged place for a long time. It is, self-consciously referred to on the occasion of anniversaries of lost uprisings and battles. It creates an appropriate context for their commemoration. It is convenient and important as a performative model of living history.

Jacek Dobrowolski wrote with remarkable accuracy about the durability of this kind of participation in the celebration of historical disasters:

From the battlefield we import to the ecclesiastical and national sanctuaries the remains of those who fed Motherland-Poland with their own blood, honouring them as relics of Christian martyrs and caring more for them than our living fellow humans. We take greater satisfaction in dealing with the dead during the call of the fallen than in getting to know those who are alive and co-existing with us. We enjoy the role of deep mourners, thus giving testimony of our martyrdom and masochistic narcissism and love our own sufferings more than trying to find the truth, which might undermine such suffering. The cult of the suffering Christ is closer to us - the Resurrected One - and thus we worship defeat rather than national victories.

A rare opportunity to trace the persistence of this model of responding to traumatic events was created by the national catastrophe of the presidential plane crash near Smoleńsk in April 2010.

It triggered initially for weeks (and later months) a sequence of ritual behaviour that appeared a seamless move from the Wilno-Kowno Forefathers to the Forefathers of Smoleńsk. Beneath the thin fabric of modernity once again shone a romantic screen. It could be found in the particular funeral rhetoric of the time, in the mass performance on the streets (under the Cross at Krakowskie Przedmieście), the burial of victims of the catastrophe, and especially spectacular in the circumstances and the course of the funeral of the presidential couple at the Wawel royal castle. Observing all these events it was hard to not take the stance that the nineteenth century goes on.

The funeral of the presidential couple (I leave aside political turmoil concerning the process of deciding where) had the same ideological and symbolic background as other major funerals of the last two centuries: the transfer of Mic- 
kiewicz's corpse from Montmorency to Wawel (1890), the mourning ceremonies associated with burial of the ashes of Słowacki on the Wawel crypt (1927), the funeral of Marshal Piłsudski and burying his body in the Wawel cemetery (1935). And just as in those cases, the funeral of the presidential couple became a rather pathetic theatrum of national mourning, resurrecting not only romantic rhetoric, but also recalling the memory of the old Polish funeral - grand theatrical staging, known as pump funebris. The tragic death of the presidential couple had to be completed with a ritual and the ritual scenario repeated sequences known from the past. "Now, when it has already been recognised", Dariusz Kosiński, chronicler of the Smoleńsk performance art, wrote,

that the president and his entourage are national heroes and their death sparked massive dramatic activities, the grand finale of the whole cycle had to be a sublime act, exceeding everything done before and at the same time following the stream of national and ecclesiastical traditions. Nothing could replace the role of the monumental burial, the only truly monumental funeral was possible at Wawel.

The Wawel Festive ended the period of national mourning not only symbolically, but also transferred the presidential couple from the normal, human, mortal dimension into the heroic (in some versions martyrological) level of the immortality.

The funeral of the presidential couple at the Wawel Castle was a consequence of the logic of the mourning drama and was designed to unite the politically divided national community (although, as one recalls it had exactly the opposite effect: the funeral was the beginning of a split within the national community, or perhaps just it disclosure). I do not care at all, however, about the political dimensions of the event. From the cultural point of view, something else is important: the mournful spectacle was a requirement of need for patriotically exalted, mythological death. Once again, as in the last two centuries of Polish history, mortal remains do not end their life in the grave, but enter the symbolic universe with great force. Freed from their materiality, they begin to mean something in another dimension. The dead are no longer among us, but have power over us. The tomb of the presidential couple was semiotically marked and now radiates outside. Corpses engage symbolically, exert pressure, act, unite and divide. One thing is certain: the dead still speak to us from the "life" of the grave; we need them and they need us. It is us who put in motion dead bodies abandoned by souls. And the fate of the living is the major stake in this game.

\section{4.}

If this briefly outlined image of the Polish theatre of death is correct it raises an important question: how should we think today about the overrepresentation of 
corpses, spirits and ghosts in the Polish imagination? How does Poland's thanatophilia look in the context of a future-oriented, uniting and secularising Europe? It seems that there is no simple and conclusive answer to these questions. And in any case, the Polish voice here is highly diversified. The performances at the seasonal invoking of the spirits, this persistent presence of the metaphysics of death in contemporary Polish mythology, is very differently evaluated both in journalism and in everyday thinking. Warring parties are well entrenched in their positions, virtually preventing any discussion. At the same time, it is worth noting, any assessment of the Polish mythology of death does not necessary coincide with one's political sympathies. Here, it seems, there is more at stake: two different models of experiencing history and two different concepts of national memory.

Hence, "mythmakers" tend to see the brighter side in thinking about our present and the past in terms of death (the romantic phantasm of "Poland as the Christ of nations", national history understood as a permanent Souls' Day revival). Moreover, they find in it a symbolic idiom of the Polish "national character". a sign of identity, which helps us to be acknowledged among the mentally formatted European nations. "Mythbreakers" in turn consider this type of thinking an historical burden that needs to be shed as soon as possible. They claim that this type of thinking is anachronistic and preserves our mentality in a thickly set martyrological sauce. Moreover, it ostentatiously does not fit into the new - future-oriented - priorities of modern Europe.

It has been said sometimes that Polish political thought is still ruled by two coffins: of Dmowski and Piłsudski. It is difficult to say, whether this sentence fully reflected in the current reality. Anyway, to me it seems much truer the conviction that two other coffins govern Polish collective mythology and symbolic imagination: of Sienkiewicz and Gombrowicz: These two names are legible emblems of two antagonistic attitudes. Either we invigorate the hearts or carp superstitions. Either we reinforce a Pole in a Pole, or we derive a Pole from a Pole. Either we consolidate native shithole or we state European modernity. Either eternal trauma and dotage, or sobriety and intellectual maturity. These coffins carry a quite different deposit of values.

But the matter does not seem so simple to me. This rigid division looks good only on paper. Certainly it does outline well the general direction of the dispute, but, while sharpening the edges of both positions, does not it allow them to capture some subtlety nor to draft an intermediate position. So how do we get out of this trap?

In this context, the comments of Maria Janion, for many years a proponent of the thesis of the undiminished power of the Romantic paradigm in Poland's postwar history is of great interest. Commenting some time ago on Ortega y Gasset's thesis about the importance of the past for building of an individual and national identity, at some point she writes emphatically: 
Culture must go with their dead, we have to go with our dead, and it is basic for us to know that they are with us. (...) I have often pointed out that Polish culture is a culture of mourning, solemnly renewed once a year. And here Mickiewicz was right when he wrote in the preface to the French-language version of Forefathers Eve, that the communication between the visible and the invisible world, the living and the dead, is an important feature of Polish culture. During his Parisian lectures he discussed this as a significant feature of all Slavic culture.

Many years later Janion wrote: "Into the Europe, yes - but only with our dead", the phrase even becoming the title of her book.

The thoughts of this talented interpreter of the works of Polish Romanticism well illustrate the essence of the problem. Because what are we really referring to here? We are not dealing with a simple reproduction of the martyrdom cliché of romantic origin. At the beginning of the transformation, in the early 1990s, Janion arged it was already the twilight of the Romantic paradigm in Polish mentality. She wrote and spoke several times about the negative influence (especially on vulnerable young people) of the romantic cult of the victim and the contemplation of death.

When criticising the historical reconstructions played out periodically on the streets of the capital, among others scenes from the Warsaw Uprising, where "old combatants and militarised children" meet, she argued about the spread of a real death syndrome. It is difficult to suspect her of naïve and slavish submission to romantic rhetoric and the sentences cited here cannot be regarded as adherence to the nationalist camp or for some form of postmodern fascination with death.

Janion's position is worthy of attention for one fundamental reason: it clearly shows that the modern memory of the dead, the strong appreciation of the presence of death in the Polish imagination, though no doubt of romantic roots, is not - and certainly does not have to be - a simple and regressive repetition of history. It does not have to be bewitched by death, some half-mad religion of death, proclaimed even by the death's indomitable knight - Jarosław Marek Rymkiewicz. Developing this thought briefly, it seems to me that one can still think about Forefathers Eve and its spiritual and culture-making dimension without falling into extremes. In other words, you can go beyond the earlier outlined, supposedly intellectually compelling, alternative. So it is not that we all are stuck in a seductive trap or that we are governed by some form of fatalism. Neither a drastic cutting of the vertical historical threads nor an immersion into the amnesia of liberal modernity, nor a mad vision of the collective Sein zum Tode, which demands the national spirit come true via national massacre. It is not (and certainly does not have to be!) a death trap. Escaping from it is not so difficult - it just needs a little patience and the necessary distance. Because maybe death itself is not a problem, as much as a way of understanding. Yet, there must be a point in the thinking process that although recognises the importance of the idea of communication between living and dead, does not make a Golden Calf in an act of hysterical idolatry out of it. 
Thus, in summary, one "against" and one "in favour" of this Polish theatrum of death.

"Against": it is impossible to discern advantages in the use, abuse and appropriation of death to martyrological-national (and in fact: pseudo-patriotic) performances and similar rhetoric. Such an understanding of it traps Polish thinking in a provincial gesture of mindless repetition of what belongs to it. It also leads to grotesque pride because of such a dubious distinction. Understood as such, death becomes a tribal totem, keeping the community in a state of permanent fixation on the point of its own suffering. This approach turns out to be a melancholic (in the Freudian sense) refusal to end mourning and culminates in a disposition, which could be called mental necrophilia.

"In favour": the memory of death, namely: the memory of our dead, of "our dear buried" (all the dead, too, even the ideologically "inconvenient") is a clear gesture of anchoring the older than the current layers of culture in the contemporary community and in this sense is a gesture of enriching. It might be perhaps an initial attempt to reject the thoughtless and idle modern decree on the ideological primacy of the future. This attitude is often reproduced in a degenerate form. It is also an attempt to plant the national community into the myth. Understood as such, the idea of "eternal forefathers" can be a solid binder of the community. In this situation the rite of "forefathers", the rite of summoning the spirits of the dead brought to the level of art and realising itself in great theatrical (and film) fiction ceases to be folk Ramot. Sometimes it becomes a spiritually harrowing experience. More than proof of the reality of such metaphysical penetration.

\section{5.}

Watching a digitalised version of Somersault by Konwicki, with leather clad Zbigniew Cybulski jumping out of the train and making his way through the bushes before appearing in a small Polish town, a provincial cosmos, strange, peculiar ("these people are dead, ghosts only"), in which the dead mingle with the living. He recalls the not too distant war. He comes, he says, to experience his own death. The film is unusual, hypnotic, with some mystery hidden in its core. At first it looks like a little thanatic version of Forefathers Eve, while towards the end - with a dancing robot in a bar - it seems a little hallucinatory version of The Wedding by Wyspiański. The movie so Polish, with its strong idiomatic stigma. War, spirits, ghosts, death. Yes, I'm home, I'm at home. Cinematographic form subjects death to the Polish art of distillation. So I dive into the past, I experience the suffering of a hero, I visit the Polish cemetery, but I do not in pursuit of a deadly fever. The memory of the recent war does not crush me to the ground, but rather opens up the longer than transient topicalities. The Polish theatre of death also has its ca- 
thartic dimension. Let Rymkiewicz dream about massacres and corpses, let others sharpen the bayonet.

\section{Bibliography}

Dobrowolski J.

2000 Dziady, czyli nie wszystko. Próba rekonstrukcji polskiego Dionizosa, „Teatr” nr 11 i 12 .

Janion Maria M.

2000 Do Europy tak, ale razem z naszymi umartymi, Warszawa.

Kosiński D.

2013 Teatra polskie. Rok katastrofy, Kraków.

Kott J.

2005 Kadysz. Strony o Tadeuszu Kantorze, Gdańsk.

Mickiewicz A.

2004 Dziady, Kraków.

1995 Najwyższym szczęściem dzieci ziemi jest jedynie osobowość. Rozmowa z Maria Janion, „Konteksty” nr 3-4.

1992 Okno do środka. Rozmowa z Andrzejem Dudzińskim, „Tygodnik Powszechny” nr 1. Rosiek S.

1997 Zwłoki Mickiewicza. Próba nekrografii poety, Gdańsk.

Stasiuk A.

2010 Dziennik pisany później, Wołowiec. 